\title{
Exceptional New York? Variations in Neoliberal Labour Relations at the Urban Scale
}

\author{
Ian Thomas MacDonald \\ York University
}

\begin{abstract}
This paper presents an argument for a serious engagement of labour studies with spatial analysis through a focused study on the labour movement in New York City. In it, I wish to make two claims: firstly, that there are spatial foundations to trade union power at the urban scale which are becoming more prominent in the current era of neoliberal globalization, and secondly, that local particularities in working class formation and institutionalization are highly relevant, if too often ignored, variables required to understand the current predicament of the American labour movement. The argument is developed by working out an intellectual puzzle posed by the New York case in particular, namely, the continued strength of unions in a city which appears to typify the political economic transformations that have essentially de-unionized the American economy.
\end{abstract}

\section{KEY WORDS}

bargaining regimes, global cities, labour geography, neoliberalism, New York City

Despite a decade of efforts to halt a long decline, the power of organized labor in the United States has reached a historical nadir. Whether measured by union density, strike incidence, or ability to resist concessions and structure labor markets, the present debility of American unions raises the question of their continued relevance even to the small minority of workers who remain organized. It is worth recalling the extent of this rout. The rate of union density came to rest in 2006 at 12 percent of the total workforce and just 7.4 percent of the private sector, the lowest figure in over a hundred years. ${ }^{1}$ Strikes, which have been all but abandoned by the labor movement, currently affect a statistically insignificant fraction - 0.1 percent - of the US workforce. The Bureau of Labor Statistics (BLS) recorded 15 'major work stoppages' in 2008, a category which logs strikes involving over 1,000 workers. In 2003, it registered only 14 such strikes - the lowest figure since this data has been recorded. ${ }^{2}$ Strikes which do occur only seem to emphasize to all involved the degree to which non-union firms now set the employment norms in these industries, the ease with which unionized employers have neutralized the strike weapon, and the inadequacy of union strategy in the face of these developments. No major American union has yet resisted employers' demands for concessions on health care costs and pensions. But this broad structural weakness of American labor is perhaps 
best measured by the movement's non-impact on the labor market: in the remarkable disconnect over the past thirty years between growth in productivity and profits and stagnation in workers' compensation, and the incapacity of workers to make significant wage gains in the period of economic expansion and low unemployment leading up to the current economic crisis.

Given this record, it is even more remarkable that the decades-old literature on the decline of the US labour movement has been eclipsed recently by an equally prodigious literature on the movement's revitalization. In the name of something new, the rebirth perspective heralds an epochal shift in labour's commitment to reorganize the workforce, to engage in more democratic practices and reorient its political strategies to social movement-styled campaigns (Mantsios 1998; Kim and Voss 2004; Fantasia and Voss 2004). In the more enthusiastic accounts, the 'new union movement' is on the verge of the 'next upsurge' and is 'now positioning itself to organize and mobilize against the neoliberal present, to become what it never has been before - a genuine counterweight to the power of U.S. capital' (Fantasia and Voss 2004: 3). It should be clear from the above enumerated figures that this is not so, that US capital has likely never seen such lack of counterweight to its power, and that organized labour is now facing not an upsurge in its ranks but what is essentially an open-shop economy. Organizational turbulence in the form of leadership transition, consolidation among national unions and a split at the federation level remains contained within the traditional framework of American business unionism.

There is merit, however, in this revivalist literature's engagement with a question rarely addressed by the decline literature, namely the issue of local particularities and the vital importance of the city as a sphere of labour politics and organization (Kriesky 2001; Ness and Eimer 2001). It is widely acknowledged that the geography of organized working class capacity has always been highly uneven in the US due to the uneven development of US capitalism itself and the failure of the labour movement to organize late developing regions and adapt to the spatial strategies of capital (Davis 1986; Moody 1988; Griffith 1988; Cowie 1999). Less appreciated is the extent to which unionization (and subsequent de-unionization) has been largely an urban process (Rathke and Rogers 2001). Throughout the postwar era, industrial national-scale bargaining structures stitched together urban-based centers of union power even while local structures of representation were strongly centralized in national (and North American) organizations. In 1960, when American union density registered little over 30 percent, density in metropolitan areas averaged 73 percent nationally and 80 percent in North Central and Western cities. As union density began rapidly to decline in the early 1980s, the national metropolitan average was still over 50 percent (ibid). Today, the differential between national and urban union strength has virtually disappeared. The erstwhile 'union towns' of Chicago (17.2), Philadelphia (15.3), Pittsburgh (11.9), Boston (12.6) and Baltimore (14.8) no longer merit the appellation. ${ }^{3}$ And yet, while the decline of US unions has been almost entirely due to the crisis of unionized manufacturing employment based in urban areas (and, conversely, the failure of unions to grow in new sectors and urbanizations), the comparative literature on de-unionization in the US is cross-national in scope, dealing with national-scale variables in institutional structures of representation or political culture (Edwards, Garonna and Todling 1986; Turner 1999; Lipset 1995; Lipset and Meltz 2004). Given the spatial unevenness in working class formation, and the historical centrality of the urban scale to the strength of organized labour, national-scale studies can be awkward constructions unsuited to more fine-grained analyses 
of local variations and urban processes. At a more theoretical level, the social production of space at whatever scale - let alone the urban - is rarely addressed in either the historical literature on the formation of the US labour movement, or the 'decline' literature that sought to understand the contours of its long descent. ${ }^{4}$ While foregrounding the city as an increasingly important field for renewed attempts at organizing poorly paid workers in service industries, the recent literature in labour studies has failed to draw upon insights on the spatiality of social relations as theorized within critical human geography. ${ }^{5}$

Critical human geography has engaged far more robustly with labour studies than vise-versa. The recently formed sub-field of labour geography, associated most closely with the contributions of Andrew Herod, promised to make critical human geography directly relevant to the strategic questions being raised in the literature on trade union revival by emphasizing the capacities of organized workers to produce particular industrial and urban geographies (Herod 1994; 1997; 2001). Marxist geography in the tradition of Henri Lefebvre and David Harvey erred, Herod asserted, in its privileging of capital as the primary subject in the production of space, and effacing the ways in which workers produce their own 'spatial fixes' as a means of furthering their autonomous economic and social interests. Even when workers are defeated in these struggles, 'the very fact of their social and geographical existence and struggle means they shape the process of producing space in ways not fully controlled by capital' (Herod 1997: 17). Indeed, many of the examples cited in support of the theoretical assertion of labour's capacity to produce space involve situations in which capital has reorganized the scale or locus of production to evade that power.

Much of the writing in labour geography has followed Herod's lead in stressing the opportunities open to labour movements in the creative use of spatial strategies, particularly at the local and global scales (Tufts 1998; Castree et al 2004; Wills 2006). This theoretical shift is reflective of some real developments in union practice in North America. In particular, the urban-based organizing strategies pursued by the more active affiliates of the Change to Win federation and the 'Union Cities' project of the AFL-CIO bear mentioning, as do new forms of cross-border labour solidarity - developments which are almost universally interpreted as aspects of the putative renewal of the American labour movement.

There is an ironic subtext to this literature: the agency of the organized working class is being reasserted theoretically just as capital is exercising in actuality its unprecedented power to reshape the North American space-economy. The renewal of the American labour movement is being declared at its weakest, most disorganized moment, and the possibilities of workers producing space celebrated as the crisis of social democratic politics unfolds. When in the early 1970s Henri Lefebvre and David Harvey were arguing that social space was produced through capital accumulation primarily and class struggles secondarily, labour movements in Europe and North America stood at the zenith of their post-war political/economic strength. Even then, Lefebvre acknowledged that 'there is no getting around the fact that the bourgeoisie still has the initiative in its struggle for (and in) space' (Lefebvre 1976: 56). The examples of defeats cited in support of the claims of labour geography the shifts in investment that resulted from the British miner's strike, the reorganization of container handling along the US East Coast as a result of the longshore workers' attempts to extend their jurisdiction inland, the internationalization of US capital aided in part by the imperialist foreign 
policy of the AFL-CIO during the cold war - sustain Lefebvre's observation. Surely the exercise of real power must entail outcomes which favour the interests of the agent wielding that power.

Why, if capital retains the initiative in its struggle over space, study working class organization at the urban scale under neoliberalism? In treating capital and labour as equally viable actors in the struggle over space and conflating levels of analysis (the abstract process of capital as self-valorizing value, on the one hand, with concrete, historical class struggles on the other), Herod and much of the labour geography literature leave the strategic terrain far too open. In losing sight of the primacy of capital accumulation in the production of space, the contradictions of this process within which labour strategy must be grounded remain hidden. I believe that there are real contradictions in the twin processes of globalization and urbanization which do open opportunities for labour strategies at the local scale, and particularly so in global cities such as New York. But an appreciation of these must begin with a recognition that capital, whose power over the production process and allocation of investment has never been effectively challenged in North America, remains the undisputed agent in the production of space. The ways in which neoliberalism has shifted the terrain of class struggle in the US to the great detriment of the working class, precisely through its control over the social production of space, cannot be understood and realistically appraised if this primacy is not recognized.

This paper presents an argument for a serious engagement of labour studies with spatial analysis through a focused study on the labour movement in New York City. In it, I wish to make two claims. Firstly, I argue that local particularities in working class formation and institutionalization are highly relevant, if too often ignored, variables required to understand the current predicament of the American labour movement. Secondly, and more ambitiously, I argue that there are spatial foundations to trade union power at the urban scale which are becoming more prominent in the current era of neoliberal globalization. These foundations arise from the ways in which capital has remade the space economy of the global city with little hindrance from organized labour. Trade union strategies of producing what Herod suggestively calls 'labour's spatial fix' are built on top of these foundations where institutional legacies and have made this possible. The argument is developed by working out an intellectual puzzle posed by the New York case in particular, namely, the continued strength of unions in a city which appears to typify the political economic transformations that have essentially de-unionized the American economy.

New York City, historically a center of union power, presents a particularly anomalous case in contrast to the general evisceration of the American labour movement. Although weakened and defensive as are unions everywhere, the New York City labour movement has maintained a level of union density, at 24.6 percent, that ranks the metropolitan area second among American cities (behind Buffalo, NY) and that compares favorably with Canadian jurisdictions such as the Greater Toronto Area (25 percent). Density rates in both the public and private spheres of the New York Metropolitan Area are exactly double - 70 percent and 14 percent, respectively - the national level. The conventional explanation for the particularity of New York City - that a high unionization rate is attributable to exceptionally elevated rates among public sector workers - cannot account for the variation. The abnormally high level of public sector unionization in New York itself is deserving of explanation. But some unionized sectors in the area's private sector, such as the heavily organized hotel industry, are also large outliers when compared with national figures. Other private sector 
industries, the taxi and for-hire car industry, for example, are organized almost nowhere else in the country, while the New York City economy disproportionately concentrates other industries, such as live entertainment, which are almost wholly organized.

Another, more tractable account of the particularity of New York emphasizes its legacy of left politics and culture, its history as the cradle of American syndicalism and the unique formation of the city's immigrant working class. The city clearly stands apart in American political development as a social democratic formation. As an enduring 'liberal' polity it might best be described as 'an island off the coast of America', to use Gray Spalding's evocative phrase. But there was once a multiplicity of social democratic union towns - most of which were as heavily organized as New York. Moreover, longitudinal data reveal a certain stability in union density in this city relative to the inexorably downward national trend in the neoliberal period (c1975-present - see Figure 1). Along with New York State, New York City is one of very few jurisdictions in the country to experience any expansion in union membership in recent years. The city's particularity cannot simply, therefore, be the outcome of a cultural legacy. The ability of the city's unions to retain a stable level of bargaining coverage suggests a more structural explanation.

The ability of the New York labour movement to retain a level of social power, of not only union density but also labour market influence and clout with city politicians, is a significant anomaly. New York City is not Buffalo, NY. The only metropolis north of the Sunbelt to experience core-city growth since the urban crisis of the 1970s, New York remains the country's most populous city and largest economy - the eleventh largest in the world if it were indeed a country to itself. With the US's two busiest airports by volume of cargo and passengers and the leading port complex on the eastern seaboard, the New York metro region retains its importance as the premier transportation hub linking the US economy with the EU and the rest of the world. Its top ranking as a center of financial power remains unchallenged despite fears to that effect in the 1970s and 80s and the challenge posed to it more recently by the City of London. ${ }^{6}$

While significant, the case of sustained union strength in New York is also somewhat paradoxical, given that the causes held responsible for the decline of organized labour nationally globalization, neoliberal policies, the decline of industry and the rise of new service sectors, the restructuring of employment relations and anti-union managerial strategies - apply equally to this city. New York is the country's most internationally articulated economy, has experienced the virtual destruction of manufacturing employment and rapid rise of services, was the first American city to be 'structurally adjusted' following the fiscal crisis of 1974-5, and is, naturally, home to the nation's most accomplished union-busting law firms and union avoidance consultants. The extreme income inequality in the city - the widest in the country - testifies to the thorough transformation of New York City's political economy from incubator of the New Deal to paragon of neoliberalism. As a neoliberal, postindustrial city, New York exemplifies the changes that have made the United States an essentially non-union economy typified by low wage employment. That New York is also a 'union town' makes for a significant, paradoxical variation worthy of detailed study.

This paper does two things. Firstly, it locates the continued strength of New York City's labour movement in the specific formation of the city's political economy and its working class. In each period studied, from its early development as a manufacturing and financial power, to the postwar era and the transition to neoliberalism, the economic structure of New York City has stood 
at one remove from national trends - either prefiguring them, as in the process of deindustrialization and the shift to services, or exempting itself from them altogether, as in the rise of Fordist production. In part for this reason, the labour movement in New York has been better able to use its significant institutional leverage to transition out of declining and into rising sectors of the labour market. To some extent, the city's labour movement has always been out of joint with national developments. This has particularly been the case with the transition to neoliberalism, in which the city's most powerful unions have managed to defend the institutional bases of their power even as they buckled to the disciplines of the new regime.

Secondly, the paper explores in more detail how the city's largest private sector unions - the food retail workers and the hotel workers - have managed to maintain a level of bargaining power and political influence well into the neoliberal period. In each case studied, these unions have been able to preserve relatively high levels of union representation, bargaining structures and wage levels which distinguish them from their national counterparts. This has not been a result of adopting the organizing strategies championed by the revivalist literature; the New York City labour movement does not, for good reason, figure prominently here. Rather, the city's unions have maintained their power by successfully deploying essentially defensive strategies which aim to impose stability on their respective industries. Their ability to pursue these strategies with some success rests on the particular firm structures that characterize these industries and the ways in which New York has been produced as a global city.

\section{The Political Economy of New York}

\subsection{HISTORICAL FORMATION}

The economics of the city has always been the economics of location. Its history is the history of its place at the intersection of the international exchange relations, out of which emerged the world capitalist economy in the early nineteenth century. Coupling an ice-free oceangoing port to a canal-improved river that reached deep into the rapidly developing hinterlands of the US, New York enjoyed a formula of advantages unmatched by rivals Boston, Philadelphia, Montreal and New Orleans (Beckert, 2001). Due to revolutions in transportation and the reinvestment of trade profits in industry, New York was by the 1830s the foremost trading city of the North Atlantic economy, and the foremost manufacturing city of the Americas by 1860 (Vernon, 1960; Abu-Lughod, 1999). Massive investments in railroads and telegraphs further extended the city's reach into the interior, reinforcing its position as the break-in-bulk point in trade between the American and European economies as it simultaneously induced a differentiation in the region's spatial division of labour. The first de-industrialization of New York City began as resource-oriented industries subject to increasing returns to scale were relocated to the periphery of the city and into the agricultural and mining districts of the Mid-Central and Midwestern states. New industries which produced high value by weight commodities and were reliant on local external economies continued to concentrate in the city (Pratt 1974 [1911]; Haig 1974 [1929]).

Already by the close of the nineteenth century, the city's economy was marked by a recognizably modern division in its capital structure. On the one hand, the city's financial oligarchs 
had monopolized the heavy industries which now spanned an increasingly organized national economic space. On the other hand, the scale of production and capital ownership in the vast majority of the city's industries had experienced de-concentration, from 19 workers per manufacturing firm in 1860 to 13 in 1900 (Abu-Lughod 1999: 79). This tendency was particularly marked within the garment industry, where the contracting system and small-scale of production engendered 'a nightmare world of endless competition and terrifying business insecurity' (Dubofsky 1968: 43).

The formation of New York's working class and labour movement reflected and added complexity to these particularities of the city's political economy. At first a radical political force influenced by the socialism of the German 48'ers and the working class republicanism of the city's natives, by the Gilded Age, the city's craft workers had won decent wages and employment security through their effective control of the local market in skilled labour. By 1911, Pratt singled out the city's construction and printing unions in particular as 'very strong, completely organized and aggressive' even while they tolerated corrupt leaders and machine politics (1974: 98). The industrial working class of the city's garment industry - here largely influenced by varieties of Second International and Bund socialism dominant among post-1905 Jewish immigrants - were largely unorganized until a rash of recognition strikes secured unionization of the industry in 1913 (Dubofsky 1968: 85). Both craft and garment industries were characterized by fierce competition between small-scale capitals, and conceded to unionization prior to those industries in the city with higher capitalization and concentration in ownership better able to resist strike pressure. Unionization brought a certain stability to these industries - the negotiation of city-wide wage scales and workplace norms, labour discipline, and the organization of individual firms into trade councils - which was not unwelcomed by employers. Well into the twentieth century, New York City was unique to the degree that small firms were organized in trade associations for the purposes of local scale pattern bargaining (Segal, 1960: 37). The breakthrough in hotel industry organizing was made possible in part by overcoming jurisdictional disputes between different AFL locals via the formation of the New York Hotel Trades Council in 1938. The Council, under the effective leadership of HRE local 6, brought together various unions to coordinated collective bargaining in an industry that had been notorious for low wages and high turnover (Josephson 1956).

By any measure, the city remained a manufacturing powerhouse well into the 1950 s. But manufacturing employment in the New York metropolitan area did not grow as fast as in the US in general, regardless of the fact that it concentrated consumer industries slated to experience rapid growth in the postwar era. In research conducted under the auspices of the Regional Plan Association (RPA), Raymond Vernon and his colleagues noted that the region's employment underperformance during this period was prominent among industries which they classified as 'footloose' and 'labour-sensitive' and much less pronounced among those they identified as 'transport-sensitive' and 'external-economy' (Vernon 1960). A further differentiation was occurring within industries. New York's manufacturers responded to the new competitive pressures occasioned by continual improvements in transportation by separating out aspects of the labour process that could be de-skilled and relocating them to lower wage jurisdictions, particularly to the industrializing South and the depressed, de-industrializing areas of New England. Manufacturing in New York, a city devoid of any particular resource endowment, disadvantaged by congestion and relatively high 
wages, and further and further removed from the country's Westward-bound center of gravity, was increasingly perched on an historical legacy - in the supply of skilled labour and the clustering of suppliers and customers which forms over a long period of industrial activity - and in the dwindling transport cost advantages of producing near a massive urban market.

These tendencies towards industrial displacement and specialization in the production process reinforced the uniqueness of the city's capital structure and labour markets. New York City effectively outsourced Fordism (Fitch 1993; Abu-Lughod 1999). It disproportionately retained industries where firms were typically one-plant operations which produced in small batches with few employees and little mechanization while it solidified its role as headquarters for the country's largest industrial concerns (Vernon, 1960: 72). In further distinction from the Fordist model, the city's labour market was decisively weighted towards local-market as opposed to national-market industries. $^{7}$

The nationwide strike wave which followed the end of the Second World War dramatized the implications of this market structure for the specificity of labour relations in the city (Freeman 2001). In New York, where workers participated to an equal degree, strikes were concentrated in the local market services sector and drew their power not from their economic impact on the firms immediately affected, but rather from their ability to bring the city itself to a halt. The first strike in the period, of fifteen thousand building service employees including elevator operators, idled a million and half workers and cost the city's economy an estimated one hundred million dollars. A telegraph strike downed communications into and out of the city, a trucking strike emptied grocery shelves, and a transit strike stopped commuter travel. A strike by tugboat workers in the winter of 1945 led to a fuel shortage in Manhattan and calls by the Mayor to close all public, commercial and industrial establishments in the city. Three further strikes on the waterfront crippled what was still the world's largest port. These strikes did not last long - a week or two at most, three days in the case of the tugboat strike - since they led to swift political intervention and arbitrated settlements which often conceded to the economic demands of the strikers.

The use by organized workers of their strategic power in local labour and product markets was registered in wage settlements. Wages in these sectors of the city's economy, particularly in the well-organized building services, construction, transport and hotel industries, were consistently above those in comparable metropolitan jurisdictions and tended to exert an upward pull on wages in other sectors (Segal 1960; Hoover and Vernon 1959). In those metropolitan industries that were subject to national pattern bargaining regional wages were comparable cross-nationally. But in the garment industry, where national pattern bargaining and wage equalization was never realized, wages in New York were consistently below metropolitan averages. The RPA studies concluded, however, that since most of the region's industries were not wage-sensitive or nationally-oriented, the regional economy would retain its peculiarly high wage structure into the foreseeable future and what impact elevated rates of unionization and labour militancy had on firm location decisions would abate in future decades as the geographical distribution of collective bargaining becomes more uniform throughout the country' (Hoover and Vernon 1959: 35).

Precise figures for metropolitan union density in this period are not available. Joshua Freeman, whose work deals extensively with the city's labour movement in this period, estimates that over a million workers in New York City, representing between a quarter and a third of the total 
workforce, paid union dues in the early 1950s (Freeman 2001: 41). A 1957-8 BLS survey estimated union coverage of what it termed 'plant workers in all industries' in the New York Metropolitan Area at 80-84 percent, a level similar to Philadelphia, Minneapolis and Los Angeles. Union coverage in New York, however, was distinctive in that it mirrored the unmatched diversity of the city's industries and services and that it was precocious in establishing a beachhead in the public sector, largely as a consequence of the transit workers retaining their capacity to bargain collectively when the city began assuming control of the bus and subway system in 1940. But the New York City labour movement was more impressively unique in the richness and breadth of its political, cultural and education institutions, in the close if often conflictive ties between city unions and the Left, and the influence it exerted in municipal politics first through a series of third party formations and subsequently in the postwar era through liberal-labour coalitions within the local Democratic Party (Freeman 2001: 55). It left its mark in a city welfare state verging on a social-democratic model, one that was exceptional in the country to the extent that it performed 'non-common' municipal

government functions such as health care, mass transit, free higher education, and public housing (Fuchs 1992; Abu-Lughod 1999; Freeman 2001).

\subsection{PRELUDE TO NEOLIBERALISM}

If New York approximated even a truncated version of social democracy, it never challenged the primacy of the city's financial and real estate interests. Their mark on the city was most visible in the planning process, in the long-term decision making that would define the role of New York in the intercity hierarchy and limit the choices of the city's lesser political and economic actors. Even as the labour movement built up its base in the city's massive industrial and manufacturing complex, an elite group of financial and real estate barons planned for the de-industrialization of Manhattan. As early as the 1920s, these interests championed the construction of a highway, tunnel and bridge network that would encourage the shift of manufacturing to the city's periphery, allow for the transfer of New York's port operations (on which half a million jobs in Manhattan depended) to New Jersey, and permit higher concentrations of office building in the downtown core (Kahler 1993). A renewed push to displace the city's industrial center accompanied the postwar boom in the US economy and the concomitant expansion of corporate headquarter office space in Manhattan.

New York, which in 1947 was the largest manufacturing center in the US, would enter the de-industrialization process decades before the transition to neoliberalism and earlier than other cities in the Northeast. John Griffin's 1955 study of industrial location was the first to understand how city planning was precipitating industrial relocation away from the city (1955). As Raymond Vernon's studies for the RPA were being published in 1959-61, the city was entering a period of marked manufacturing loss that would spiral into the deepest and most protracted process of deindustrialization witnessed in the United States. Between 1947 and 1973, when manufacturing employment was still growing nationally, factory jobs in New York City were halved from 1.12 million to 543,000. While a crisis for the workers concerned, this process did not much trouble the city's planning authorities, and still less the real estate moguls and developers who had more remunerative uses planned for lower Manhattan and Midtown. Echoing these interests, a planning brief written for Mayor John Lindsay in 1968 argued that 'In the long run, New York does not want 
to retain the low skill, low wage segment of its industrial mix...The displacement of manufacturing activity in the CBD [central business district] is the complement to the expansion of office construction which results in more intensive land use, higher investments and more jobs than manufacturing activities they displaced' (Fitch 1993: 120).

Manufacturing may have been drawn out of the city by the lure of lower costs and open space, but it was also pushed out. The city's industries should have benefited from the liberal trading system that American hegemony had secured at the end of the war. Instead, it was New York's financial sector which would claim the benefits of the new international order as the city effectuated a transition from the financial center of the US to the center of world-embracing American finance (Panitch and Gindin 2005). Manufacturing New York, which had formerly existed in isolated proximity to the city of financial power and real estate speculation, did not enter into the city's plans to consolidate its role as a global city except as a barrier to its fruition. The inability of the city's labour movement to prevent or negotiate the terms of this transformation - concretely, the failure to secure the necessary infrastructural investments and preserve industrial land use - exposed the limits of labour's influence even at the moment of its greatest power.

While the city awaited the promised upsurge in white-collar employment that would compensate for manufacturing job loss, the only sector to experience any significant job growth in this period was in municipal and state government services. By the early 1970s, the municipal government alone employed over 400,000 workers, which at 10 percent of the city's total workforce outnumbered employment in the garment, banking and longshore industries combined (Horton 1973: 6; Freeman 2001: 201). As the industrial unions hemorrhaged members throughout the 1960s, the municipal and public sector unions grew spectacularly. The city's labour movement was the first in the country to make decisive inroads in government employment by mobilizing its superior political, organizational and financial leverage to secure the success of the new organizing campaigns (Aronowitz 1991: 69-74). The question in New York was not whether public sector workers would be organized, but which unions would win representation of the largest workplace units. Under pressure from his allies in the city's labour council, its president Harry Van Arsdale in particular, Mayor Richard F. Wagner gradually extended bargaining rights to the city's workers upon his election in 1954. In 1958, Wagner passed an executive order that granted city workers the right to organize and bargain collectively but not to strike, which remained proscribed by state law. It was a shrewd move that redounded to Wagner's political benefit. By drawing the city's disparate personnel departments into the bargaining structures controlled from his office, and by intervening with the Labour Board in the certification process to favor some unions over others, Wagner attached the new municipal unions to the broad coalition that would return him to power for a second and third term (Aronowitz 1991: 38-39).

Raymond Horton's careful study of municipal labour relations in this period concluded that the city's workers saw no improvement in their wages and benefits as a result of this highly managed process until 1965, when they began to put their new organizations to use. 1967-1971 were years of renewed working class militancy across the US, and as was true of the postwar strike wave, New York City unions participated to an equal degree. As a result of de-industrialization and the shift in employment towards local government services, job actions in the city this time were even more disproportionately concentrated in the services that made the urban economy function. The city's 
welfare workers were the first to test the bounds of the new municipal labour relations by striking for 28 days in 1965. Transport workers followed in 1966, striking the city's buses and subways for 12 days. Teachers struck twice, once in 1967 and again in 1968. In private services, they were joined by newspaper, UPS, and longshore workers. New York federal postal workers touched off a national strike when they walked off the job in 1970 (Spear 2005: 61). Even if these strikes threatened to rend labour-community coalitions and threw into relief anti-union sentiment among the city's increasingly conservative electorate, the strikes were everywhere successful. ${ }^{8}$ Union leaders jailed under the terms of New York State's Condon-Wadlin Act were released, workers fired for striking were reinstated, and arbitration boards generally acceded to union demands. In one of the last effective demonstrations of city-wide labour solidarity, the leaderships of the city's unions threatened sympathy strikes if the national guard were called in to replace striking sanitation workers in 1968 (Spear 2005: 64). The victory of this last strike was particularly galling to the embattled ruling class of 'Strike City.'

The state and city governments responded to the strike wave with new legislation that would attempt to contain and routinize this higher level of contention. In reaction to the 1966 transit strike - in which the Condon-Wadlin Act proved ineffective because too punitive - the New York State legislature passed the Taylor Law, which while granting the requirement that municipalities bargain in good faith also secured a more effective ban on striking by targeting penalties at the financial viability of the unions and their individual members. In response to the Social Service Employees' strike of 1964, the city government created a tripartite apparatus - the Office of Collective Bargaining $(\mathrm{OCB})$ - with the authority to determine the scope of negotiations and the bargaining unit, and to make binding arbitrations. It established the Municipal Labour Committee (MLC), a peak labour organization through which labour would select its representatives on the OCB. Some have seen this shift to tripartism in municipal labour relations as the ultimate capitulation to labour (Horton 1973:79. Its immediate effect was to concentrate union representation, narrow the scope of negotiations to wages and benefits, and promote inter-union stability. From 1968 to 1975, the number of municipal bargaining units would decline from 400 to 100 , greatly facilitating the ability of both management and the union leaderships to coordinate their bargaining positions (Lewin and McCormick 1981). Still, unions competed amongst themselves for the best settlements, which generally followed the pattern set by the strategically placed public transit workers. Public sector bargaining would not be fully centralized until the fiscal crisis, at which point the political content of the new institutional accommodation would be more clearly revealed.

The new bargaining regime did secure wage gains, relative labour peace, and the virtually complete unionization of the city's workforce. The phenomenon of 'wages push' was not unique to the city - it was a general feature which began to squeeze the profits of the country's heavily unionized industries concentrated in the North Central and Midwestern states. Nor was the wages push among municipal workers out of line with compensation in other union cities. Data compiled by Ester Fuchs shows that 'average expenditure per municipal employee was quite similar in New York and Chicago during the pre-fiscal crisis period' (Fuchs 1992: 124). In New York, however, municipal spending did rise more rapidly than in comparable jurisdictions. ${ }^{9}$ More so than in other cities, the city of New York during the Wagner and Lindsay administrations (1954-1973) attempted to contain the urban crisis occasioned by de-industrialization through bolstering the redistributive 
quotient of city spending and by adding to the city's workforce rolls. In the three short years at the height of social and labour movement mobilization, the city budget grew by over 50 percent (Shefter 1993:106). On the eve of the 1975 fiscal crisis, the city government employed 48 workers per 1,000 residents, compared with 15 in Chicago, and spent an exceptionably large portion of its budget (34 percent) on public welfare. ${ }^{10}$

New York was able to fund this expansion through fiscal transfers from the state and federal governments and a steady tax base premised on the expansion of the CBD. The calculus changed, however, when the city was hit by an economic downturn in 1969-70 and the much deeper 1973-5 world recession. Federal funds were cut back when Nixon declared that the urban crisis had passed. From 1969 onwards the city resorted to debt financing to cover operating shortfalls. The New York banks were willing to buy city bonds until the crisis revealed the precarious position of their real estate speculations and lending profile. They stopped lending to the city and by October 1974 began selling off its securities, leaving the city unable to cover its operating expenses. In response to the crisis this precipitated, a new state-chartered agency - the Municipal Assistance Corporation - was formed to issue another round of New York bonds which would be secured by its control of the city's revenue stream, ensuring that bond holders would be paid before all else. When even this failed to force austerity on the city and its municipal workers, the bankers assumed direct control of the city's financing, program spending and labour contracts through the Emergency Financial Control Board (EFCB), a new state body. ${ }^{11}$

The New York City fiscal crisis is often discussed as the result of a gap between expenditures and revenues which was corrected after a period of government retrenchment and renewed economic growth. ${ }^{12}$ But the fiscal crisis as a political crisis was resolved as soon as it was determined who would bear the burden of its resolution: either the bondholders or the city's employees, the poor, and broader working class. The more radical voices in the labour movement favored a general strike and the devaluation of the city's bonds through bankruptcy proceedings. This was a minority view. The overriding goal of the municipal union leadership during the crisis was to preserve the institutional sources of their power, firstly the recognition of their bargaining units and secondly their membership base (Spear 2005: 171). Their greatest fear was that bankruptcy proceedings would end in the voiding of their contracts. In concession bargaining, they accepted the loss of 60,000 jobs, wage freezes for three years and increased workloads. The concessions were negotiated through the MLC and imposed relatively equally on its constituent members. The regime of competitive pattern bargaining was eclipsed by peak-level bargaining through which the EFCB imposed an incomes policy on the city workforce as a whole. 'For both union leaders and city and EFCB officials', Robert Bailey explains, this 'tended to minimize the political costs of retrenchment by spreading them around' (1984: 79). In other words, the structure of collective bargaining reached its most concentrated, most 'inclusive' form at the moment when this facilitated the imposition of austerity by providing the union leadership further insulation from their members.

The disciplining of municipal workers, it should be emphasized, was not simply externally imposed on their unions; the discipline was also internalized as a result of their efforts to negotiate its terms. The use of pension funds as bargaining leverage illustrates the dynamic. Beginning in 1975, municipal unions began transferring their pensions into the lower-yield city bonds, gradually assuming the city's debt as the banks divested themselves of their holdings. This had contradictory 
effects: on the one hand, it strengthened the unions' position vis-à-vis the EFCB, ensuring that it would not unilaterally rewrite their contracts, and thus allowed the unions to preserve at least the appearance of negotiation; on the other hand, it internalized the pressure to adopt a concessionary stance in future negotiations since a default would increasingly be born by the city workers themselves. The political strategies of the municipal unions began to shift as they became ever more concerned with maintaining a consensus around negotiated austerity. In 1977, they initiated a working group that brought together the municipal unions and the city's investment banks to better coordinate the restructuring, which included the promotion of tax cuts, retrenchment in welfare spending, and the endorsement of city-boosting projects. In 1978, the municipal unions were granted the 'agency shop' - an arrangement where union dues are automatically deducted from the pay of all workers covered by the union contract. This was a long-time demand of the unions, and its conferral in 1978 was widely regarded as a reward for the leadership's responsible behaviour. By the 1981 city election, the municipal unions would conspicuously absent themselves from the campaign waged by the rest of the city's labour and progressive movements against neoliberal Mayor Ed Koch. ${ }^{13}$

The New York which surfaced from the crisis was fundamentally altered from the city it had been before. The crisis afforded the opportunity to turn back the gains that the city's poor, its ethnic minorities and working class had made in the postwar era and remake the city to better suit the interests of financial capital. The laying off of city employees, the cuts in social spending and wage rollbacks comprised the destructive facet of this restructuring. Its creative moments can be located in the new forms of accumulation that would henceforth without question dominate the city's economy and the new governance structures and class coalitions that would define its politics. The new regime did not wipe the slate clean; rather, it incorporated existing institutions, including the labour unions and collective bargaining structures, and turned them towards outcomes which reflected the new balance of class forces. The transition to neoliberalism in New York served as a model/warning for other cities, for national-scale changes, the structural adjustments forced on the Third World, even for the bail-out of the auto industry (Zevin 1977; Tabb 1982; Harvey 2005). But in working through rather than destroying the institutionalizations of class relations and urban form that were distinct to the city in the postwar era, the neoliberal regime which emerged in New York also exhibited meaningful variations.

\section{Neoliberal New York}

\subsection{THE NEW REGIME}

From its origins in the early 1980s as a series of institutional reforms designed to restart capital accumulation after the collapse of the postwar boom, neoliberalism has matured into a relatively stable form of social rule across the advanced capitalist and underdeveloped world. Initially a solution to the long downturn signaled by the 1973-5 recession, neoliberalism emerged first in the US and was here pushed to its furthest extent. While the nation state remains the primary locus of class rule, the city has emerged as a key site in the innovation of neoliberal forms of governance and consent. As has been extensively theorized in urban political economy, the deindustrialization of the 
city core, suburban flight and the retrenchment of federal welfare transfers in the early 1970s promoted a surge in interlocality competition (Harvey 1989; Brenner and Theodore 2002). In response to these competitive pressures, local states and city-boosting alliances have formed around strategies designed to preserve the values sunk in the urban space and built environment. Characteristically, these have involved private-public partnerships linking the city government to financial and real estate capital, but they have also extended deep within civil society to include unions and community groups. By breaking apart the alliances which resisted austerity and reconstituting them along particularistic lines, these urban partnerships have served as powerful sources of political and ideological support for the neoliberal regime. This is in spite of the everywhere regressive implications of the strategies pursued by these coalitions: the enforcing of discipline in local labour markets; the shift in taxation from property and high income individuals to consumption; the tax abatements to real estate interests and large corporations; the redirection of city revenues from redistribution and public services towards high profile projects designed to promote the city as a place of luxury consumption, a tourist destination and head office center for the highly prized professional and business services; and the further separation of decision making and city planning from the democratic process. These inter-local competitive strategies have profoundly affected distributive outcomes in cities, furthering the tendency towards income polarization and exacerbating uneven development between the ever more exclusive ranks of 'world-class' cities and the failed, bankrupted ex-urbs of the industrial/post-industrial hinterlands.

In relation to other cities, even of 'global cities', New York has played a distinctly active role in this transition to neoliberalism given its undiminished centrality to American finance. In the wake of the oil crisis, the already highly internationalized New York banks positioned themselves as the central node in the circulation of surplus dollars and government debt, helping to bring into being the new international financial markets and the regulatory frameworks that would come to discipline industry and foreign governments after the Federal Reserve's move to hike interest rates in 1979 (Panitch and Gindin 2005). The use of restrictive monetary policy to force through the austerity measures and corporate restructuring deemed necessary to reassert the competitiveness of the American economy and protect the investments of US finance built up the role of the Federal Reserve within the US state and, through this institution, the influence of New York's financial community (Shefter 1993). Neoliberalism - the 'financialization of everything' as David Harvey (2005) has described it - thus confirmed the primacy of New York in the league tables of US and world cities regardless of any contribution local boosterism may have performed. New York's monopolization of the uniquely qualified professional services required by the merger and acquisition movement, its concentration of the most internationally active US banks, and its unmatched liquidity favoring it as an entry point for foreign financial investment ensured that the city would not decline, as other Northeastern cities would, in consequence of de-industrialization.

Neoliberalism has accentuated the particular industry mix and firm structures that have long defined New York City, namely the disproportionate weight of locally-oriented services as opposed to nationally-oriented manufacturing, on the one hand, and the extending spatial reach of finance, corporate headquarters and professional services on the other. Manufacturing continued its post1947 decline throughout the 1970s and 1980s, particularly in Manhattan and within sectors identified by location-quotients as export-oriented (Drennan 1991; Sassen 1991). What remains of 
the export-oriented apparel industry - still the most significant in terms of manufacturing employment - is reliant on the low wages and skills of the city's new immigrants and its location in an international fashion capital. The remainder of the much-reduced industrial sector provides goods which can only profitably be produced locally. Wholesale trade, also formerly among the city's national-market oriented industries, declined significantly throughout the 1970s and 80s (NYC Department of City Planning 1993). Among externally-oriented industries, only finance and professional and business services have shown strong growth. In these sectors the trend has been away from national industrial headquarters towards internationally-oriented American investment banks, producer services including legal, advertising and accounting, and US branches of foreign banks. Employment in these industries has only moderately increased since most of the middle-level paying clerical and back-office positions are not retained in the city. This leaves low-paying private and social services, most significantly the health care and hospitality industries, to account for most of the employment gains in New York over the past several decades (Parrott 2001: 51).

As has been widely noted in the 'dual city' and 'global city' literatures, New York City prefigured the transition to the highly polarized wage structure characteristic of the service economy. Less noted, until recently, is the more extreme gap between wage and investment income associated with the 'financialization of everything'. Since the fiscal crisis, New York City has consistently exhibited higher levels of unemployment and poverty and slower wage growth than has been the case nationally. It has been more susceptible to the boom-bust cycle, typically leading the country in layoffs at the beginning of a recession and trailing in job growth in the recovery. Job creation has concentrated at the lower end of the wage scale as middle-income paying jobs are slowly squeezed out of the local labour market. This was particularly evident in the 1990s, when employment growth was limited to jobs paying less than $\$ 30,000$ yearly and the proportion of middle-income jobs declined (ibid, 49). At the other end of income distribution, investment income and earnings in the professional and business services industries surged with the rise of stock valuations and commissions paid in corporate restructuring. By the mid-1990s, the securities industry alone would account for almost half of the city's growth in real earnings (ibid, 47). The resulting tendency towards income polarization is more concentrated in the city than the state and more concentrated still in the city core than in the outer boroughs and metropolitan region (Beveridge 2003; Renwick 2006). Since the city is devoted to the monoculture of finance and is so wholly reliant on the service sector to employ its post-industrial proletariat, it is not surprising that this should be the case.

The compromises struck in the transition to neoliberalism have profoundly altered the political orientations and bargaining strategies of the city's labour movement, slowly draining them of their role in class formation even as they remain relevant as defensive organizations for the immediate economic interests of their members. This slow decomposition has been uneven between sectors and unions, but three tendencies stand out: the balkanization of labour's political strategy at the municipal level; the decadence of internal union political life; and a slow and uneven decline of union density.

One implication of the shift in the city's labour market from national-scale bargaining in industry and manufacturing to local-scale bargaining in private services and the public sector has been the increasing centrality of municipal politics to union strategy. City politics has always been important to the municipal unions and the construction trades, but the municipal government's role 
in zoning, licensing and labour market regulation makes it relevant to most unions in the locallyoriented private services as well. Because this shift has occurred in a context of extreme labour defensiveness and retrenchment and the collapse of class politics, the city's labour movement has been unable to engage at this level with any degree of unity. A major axis of discord runs between public and private sector unions. ${ }^{14}$ The transformation of the municipal unions, from the city's most radical in the 1960s to the supporters today of whichever politician promises the best contract, has been touched on above. Their preoccupation with securing their interests in the revenue and payroll divisions of the city's budget has made some of them foes of efforts to pass municipal living wage campaigns championed by unions in private services. Other fault lines run between private sector unions. The construction unions, which continue to dominate the Central Labour Council, are broadly aligned with the real estate and developer lobbies to promote capital spending and the rezoning of industrial land to allow commercial and residential construction. Other private sector service unions, such as food retail unions, have been more concerned with using the city's limited regulatory powers to establish wage and benefit floors in the local labour market and to stabilize the industry and firm structures in which they are still represented. Globalization is opposed by the remaining manufacturing unions while it is the bread and butter of the city's airport and port workers. The Central Labour Council, whose traditional role is to coordinate the political activities of the city's local unions, has been unable to surmount these divisions and the city's most politically active unions are in any case not affiliated. The erosion of party structures in city politics, the reemergence of Tammany-hall type machines built around individual mayoral candidates, and the shift in power away from city council towards the office of the Mayor have contributed to labour's fissiparous political strategy. Organized labour has retained influence on city council that has proven effective in leveraging bargaining and organizing strategies, as discussed below.

Of equal concern is the ebbing away of what traditionally has been a very active internal union life. The opposition currents which were well entrenched in the city's unions in the 1970s, and even as recently as the 1990s, have declined significantly. Internal opposition survives in the teachers and transit unions, and a number of unions are left-led, such as SEIU 1199. But the lack of opposition to continuing problems with corruption and undemocratic practices suggests that 'workers have given up on their own organizations', and the trend is worrisome enough that a highly-placed official in the labour movement can afford himself the luxury of articulating the fact. ${ }^{15}$ Union newspapers are one-way vehicles of communication from officials to the rank-and-file and rarely permit publication of a critical voice. The tendency among reformers aiming to remove corrupt leaders and grow the union membership has been to concentrate power at the highest levels of the union bureaucracy, further closing down the spaces in which rank-and-file leaders can emerge and members feel that they are participating in their own organizations. ${ }^{16}$

De-unionization pressures throughout the neoliberal period have arisen from a variety of sources. The re-zoning of mixed industrial use land has continued apace, extending into the last corners of industrial New York, and the heavily unionized port facilities have been entirely relocated out of the city (Pratt Center for Community Development 2001). The construction trades, which formerly dominated their respective craft labour markets, have lost considerable density in part as a result of their own corruption and mob-rule. ${ }^{17}$ Non-union construction sites have become common in the outer boroughs and in smaller-scale projects, while the unions have maintained representation 
at the large, government-funded projects such as Freedom Tower, new stadium construction and public housing through political pressure exerted on city government. The successful organizing in the late 1990s of largely immigrant demolition workers stands out as a rare organizing victory in this sector, where non-unionized recent immigrants are often employed at half union scale, without benefits, skill development and the use of safety measures. Contracting-out of city services and privatization, begun under Ed Koch and intensified under Rudolf Giuliani, has reduced the rolls of unionized public employees. In some cases, such as the privately-run Business Improvement Districts (BIDs), sanitation and maintenance work formerly done by city workers is now performed by BID contracted non-union firms. In other cases, such as the privatization of child care, the unions have retained representation or have re-unionized the newly private sector workers. In noted contrast to the rest of the country, there have been no outright attempts to destroy public sector unions, which remain powerful brokers in city politics. A high-profile attempt to break the newspaper union in 1990 was a spectacular failure due to the broad base of support the city's labour movement was able to mobilize (Freeman 2001: 233).

In private services, the record has also been mixed. Unions have maintained high density and relatively high wages in the city's hotels and building services, which lead the country in union coverage and wage and benefit levels, while in other private sector services, such as food retail, unions have failed to maintain representation and decent wages in line with national trends. In both cases, the extent of competitive pressures are confined to the local or metropolitan markets, and the challenge for unions has been to maintain a level of representation to sustain their bargaining power in a context of rapid employment growth, attempts to informalize work relations, high rates of firm turnover, and new forms of delivery and niche markets. The last two factors - rapid firm turnover and constant emergence of specialized markets and service delivery - are particularly relevant in New York, where high commercial rents sustained by the finance and producer services industries are destabilizing to firm tenure and where high income consumers are particularly fickle and discriminating. As a discussion of the medium density food retail and high density hotel industries reveals, the priority of unions representing workers in these industries has been firstly to use their established leverage in contract negotiations and at city hall to stabilize their respective industries, and secondarily to organize new workers.

\subsection{WALMART AT THE GATES: UFCW'S STRATEGY IN THE FOOD RETAIL SECTOR}

The food retail industry has historically been a highly unionized and relatively high wage segment of the retail sector. Prior to the neoliberal turn, the United Food and Commercial Workers (UFCW) dominated local markets in the large national chain supermarkets, commonly representing 90 percent of the workforce (Reap 2006). Beginning in the Midwest in the early 1980s, however, the chains initiated what has been an enormously successful offensive against wage and benefit levels and employment structures. While the large national chains remain unionized and account for a stable proportion of total food sales across the country, union status is of ambiguous benefit to most workers. The wage and benefit differential between the largely unionized food retail and almost wholly unorganized non-food retail sector, for example, has declined from approximately 32 percent in 1982 to an insignificant level today. ${ }^{18}$ Decades of concessionary bargaining by the UFCW have 
permitted 'multi-tiered wage structures, long-term wage progression systems, erosion of higher wage job classifications to newly created low wage job classifications, and the rapid expansion of low wage part time jobs', and made the food retail industry one of the lowest wage industries in the country (Reap 2006). The failed grocery store strike in California in 2003-4 is the culmination of a long period of ratcheting down union standards in this industry, and not the beginning of a new period defined by Walmart's entry into food retail. Walmart's low wage anti-union business strategy, its now dominant position in the food retail market (15 percent of total sales and climbing) does, however, bring new pressures to bear on unionized retailers and those retailers which continue to provide health care benefits to their employees, as is common in New York.

The structure of the food retail sector in New York City differs noticeably from national patterns. Chain supermarkets, for example, were never as dominant as in comparable urban areas, partly as a result of higher rents, restricted space and a customer preference for smaller, specialized retailers offering fresher and higher quality products. In the 1960s and 1970s, many relocated out of the city to follow their middle class patrons to the suburbs, and large portions of the city, specifically the Bronx and Brooklyn, remain underserved by mid-price range grocery stores. The generic supermarket, represented in the New York market by regional and local firms such as Pathmark, Fairways, Gristede's and D'Agostino's, have continued to be squeezed by gourmet chains at one end of the market and discount clubs at the other. Alternative formats, such as online order grocer Fresh Direct, are increasingly relevant in the downtown core while the spaces and warehouse buildings opened up by de-industrialization and rezoning in the outer boroughs has allowed big box retailers to make a belated effort to enter a market that has long resisted them. Most significantly for the city's food retail sector, however, has been the inability of Walmart and its food retail Supercenters and Sam's Clubs to establish outlets in the city. Walmart has left New York to last in its attempts to move into the coastal urban markets of the US, and New York is the only major city in North America to have successfully resisted this thus far. The closest Walmart location remains Saddle Brook, New Jersey, 13 miles north of the city.

Union representation in New York's food retail is down appreciably in the neoliberal period. While precise figures are impossible to obtain, union organizers estimate that between 50 and 60 percent of the major grocery outlets remain organized, predominantly by the UFCW. ${ }^{19}$ The union's strategy has been to attempt to move into the new gourmet chains, to keep the big box chains out of the urban market, and to ignore the new delivery format, which is not expected to survive. New organizing in the gourmet chains has been more difficult than in traditional formats, partly because the clientele is less receptive to a picket and partly because owners fear that an organizing win in New York will set an example to out of town and out of state branches. In these cases, and when pickets are successful, owners will shut down locations rather than bargain with a union. Most of the gourmet chains, including Citarella, Whole Foods, and Balducci's, have thus far resisted unionization.

The use of political lobbying, community alliances and public relations to keep big box antiunion food retailers out of the urban market is a recent departure for the union. There are two ways in which a Walmart or its lesser known doppelganger, BJ's, can enter the city: either by gaining permission through the city's land use committee, or, if a space is designated 'as-of-right', without public review. Since very few spaces are so designated, and the spatial needs of big box outlets are so 
outsized, this latter option is unlikely. Walmart's first attempt to enter the city was defeated when the developer of its anticipated Queens site was pressured not to sign with the corporation. A proposal to establish a location in Staten Island will be decided later this year, but has already raised serious objections from local councilors and the land use committee. BJ's effort to establish a store in the Bronx was unanimously defeated by the land use committee in February 2005, officially due to traffic congestion concerns.

Walmart has prevailed in 'site fights' such as these across the country, most recently in Chicago and New Jersey. New York presents a more challenging engagement, however, partly because of the paucity of adequate space, but also due to the labour movement's significant influence with city council and its land use committee, along with the pull of the city's large and wellorganized small business sector. New York's labour movement has also been more united on this issue. In the New Jersey site fight, the construction unions supported the entry of Walmart for employment reasons. In New York, where the construction of a Walmart would represent an insignificant proportion of total construction jobs and where the construction job market is particularly tight due to the ongoing real estate boom, the UFCW has been able to secure the political neutrality of the Labourers and Carpenters locals and gain broader support from the rest of the city's labour movement, including the politically powerful United Federation of Teachers. The UFCW is also working closely with locals of the Teamsters, UNITE-HERE and SEIU, which have their own reasons for opposing Walmart. That the city's supermarket and small businesses have also mobilized to defeat the big box retailers makes it difficult to evaluate the relative heft of labour's political power, but the progression of a bill passed on City council intended to discourage the entry of a Walmart of BJ's by mandating companies contribute to their employees' health care puts this influence in perspective.

The Health Care Security Act (HCSA) builds on similar campaigns to use the powers of city governments to raise the living standards of low-wage urban service workers, both by increasing the minimum wage for all businesses operating in the city and by establishing a higher than prevailing wage for all businesses benefiting from city contracts. Drafted by progressive organizations including NYU Law School's Brennan Center for Justice and Jobs with Justice and promoted in the legislative process by Democrats and the Working Families Party, the original bill would have forced companies with over 35 employees in five industries (including food retail, construction, industrial laundries, building services, and hotels) to pay either three dollars an hour per employee into a health insurance plan or an equivalent in fines to the city. The bill would have protected the health care benefits of 152,000 workers and, since only 70 percent of employers in these industries already contribute to health care plans, would have extended coverage to approximately 45,000 workers in the city. While the bill passed with an overwhelming margin by city council in August 2005 - with enough support to override the Mayor's veto in October of that year - in the process of negotiations the coverage was reduced to the retail food sector only, and the threshold was increased to firms with over 50 workers or with floor space in excess of 10,000 square feet. The first retrenchment reflects the reality that only the highly unionized food retail sector lobbied hard for the legislation, while the other industries are either increasingly non-union, or, as in the case of hotels and building services, do not face low-standard competitors. Unions in these last two industries are strong enough to secure health care benefits in their contracts, and did not make the bill a political priority. ${ }^{20}$ The 
second retrenchment, to increase the employment level threshold, registers the effective lobbying of 'small' groceries. ${ }^{21}$ The result is that a political strategy which sought to use the conjunctural interests of a small sector of the capitalist class and labour movement to leverage a broader campaign in the interests of the city's low wage workers collapsed back into a particularistic, defensive maneuver that will extend coverage to, at best, 9,000 workers. Finessing the outcome as a 'pilot project' which can later be generalized to cover the rest of the precarious workforce, as the bill's supporters do, fails to recognize that this window of opportunity has now closed, and it also neglects to tell the truth about what happened in the legislative process.

This outcome raises larger questions of the UFCW's New York strategy. The failed strike in Southern California should have underscored the point that even in local service industries such as food retail, defensive strategies that seek to protect a delineated market space cannot prevail when ownership is increasingly concentrated at the national scale and competition in most formats is conducted on the basis of lowering costs, which in this industry more than others means lowering labour costs. The union's success in keeping Walmart outside city limits this long testifies to its stronger position, especially at the political and cultural level. But the strategy fails to consider the contribution that this leverage could play in a national campaign to organize the corporation, which must happen if retail workers and UFCW members are not to be reduced to Walmart wages and lack of benefits. If Walmart is to be organized in the US, as it is in Germany, Britain, and increasingly, Quebec, it will happen in a 'union town' first, where not only the retail unions but also the broader labour movement would be able to use its organizational and political resources to secure representation. If Walmart were let into New York, even without a promise to amend its business model, a successful organizing drive could serve as a powerful example to the rest of company's US workforce. Either that, or it would shut down, in which case the status quo ante would be reestablished. However, this is a 'roll of the dice' that the UFCW New York locals are unwilling to take. $^{22}$

\subsection{HOLDING THEIR OWN: UNITE-HERE STRATEGY IN THE HOTEL INDUSTRY}

As in the food retail sector, the US hotel industry is increasingly concentrated in national and continental chains which operate in the major urban markets. Typically locally-owned until the mergers and acquisitions of the 1980s and 1990s, the US hotel industry is now highly concentrated, with approximately 75 percent of the hotel rooms in the 15 largest urban markets affiliated with billion-dollar national and transnational chains such as Hyatt, Hilton, and Marriott (UNITE-HERE 2004). In part because of the broad economic spread-effects they have on the urban economy, including their contribution to downtown real estate values and the tax base, the hotel and tourism industries have become central to inter-local competitive strategies pursued by cities and privatepublic partnerships in the neoliberal era. They are therefore heavily subsidized by city governments through the construction of sports and cultural infrastructure, convention centers, and internationally-oriented place promotion. New York City pioneered these strategies in the wake of the fiscal crisis, spending hundreds of millions of dollars to burnish its image in the private-public 'I Love New York' campaign even as the city was cutting municipal services and employment. At first the city's police and firemen's unions contested this strategy with their 'Fear City' campaign, which 
warned tourists of rising crime and arson levels, but private-public partnerships around hotel and hospitality industries now typically extend into the city's unions to include, as in the case of New York, the support of the hotel and construction trades councils for hospitality-related development.

Even as the hotel industry is increasingly national and international in ownership structure, collective bargaining remains locally-based and provides highly uneven coverage between cities. Where unions have organized the majority of the local industry, firms have formed peak industry associations to prevent the large city-wide unions to play one firm against the other in negotiations and job actions. In New York, the Hotel Association of New York represents more than 200 hotels, which together account for over 90 percent of the city's total rooms. ${ }^{23}$ This breadth of coverage, which has increased under the neoliberal period, is highly unusual, as is the affiliation of the city's many hotel unions to the peak-level Hotel-Motel Trades Council, which negotiates city-wide contracts on their behalf. Also rare is the success of New York's hotel unions in bargaining for card check neutrality, an arrangement that allows the union to expand to new workplaces without employer resistance. In the union strongholds of New York and San Francisco, where density in the standard, full-service hotels ranges from 80 to 90 percent, wages for housekeeping start at $\$ 19$ an hour. The average wage in New York's unionized hotels, at $\$ 21.50$ an hour with dental, heath, pension and vacation benefits, are the highest in the industry. ${ }^{24}$ In Chicago (62 percent) and Los Angeles (32 percent), the comparable starting salary is $\$ 11$ an hour. In low-density Seattle (20 percent) and non-union cities, wages for the same work average $\$ 8$ an hour. It is variations in local union strength, and not room rates or occupancy levels, that accounts for the wide disparities in hotel industry pay.

In the case of New York, tourism-related industries have emerged as the leading source of employment in the services sector and, in the case of hotels, one of the very few that offers decent wages and family-supporting benefits (Fiscal Policy Institute, 2005). Occupancy and room rates have recovered to their 2000 peak after the city-boosting campaigns which followed September 11, although it is not clear that boosting is what the industry requires. Throughout the 1990s and into this century, New York's hotel space increased only moderately and then began to decline as hotels shifted from being venues for large-scale conventions, to catering to smaller but more profitable business meetings. In what for most cities is the highly-prized convention business, for example, New York hotels turn away an estimated $\$ 1$ million a day in business and have been converting these expensive exhibition spaces into high-tech meeting rooms and health clubs (Gabriel, 1997). Smallerscale, more exclusive boutique hotels are also growing rapidly to serve a largely professional clientele, while new construction in the traditional full-service tourist and business hotels stagnates, especially in Manhattan. A more significant erosion in hotel space arises from condominium conversion, a relatively recent phenomenon associated with the city's booming real estate market. As a result of the conversions, New York lost over 3,000 hotel rooms in 2004-2005, and if projected conversions in eight other large city hotels proceed, this figure could double. Even as the industry peaks in profitability and capacity, employment levels in the city hotel industry have declined by a seasonallyadjusted 5 percent over this period, a magnitude normally associated with a recession (Fiscal Policy Institute 2004).

Accordingly, one of the primary concerns of New York's hotel unions in the current 2006 country-wide negotiations is not wages, benefits or card check neutrality, but contract language 
aimed at preserving industry stability. ${ }^{25}$ Since the unions are almost wholly based in the major business and tourist full-service hotels, and have shown no interest in the outer-borough low-cost hotels or in the new boutique segment of the market, hotel conversion and firm turnover are the greatest threats to the union's market power and membership base. This is reflected in the trade council's demands for tripled severance pay if hotels are converted to condominiums and for measures that would deter management from violating the terms of contracts, under-funding its pension and health care contributions, and illegitimately filing for bankruptcy. The council has removed the Hyatt from the city-wide agreement in an effort to isolate it because of consistent contract violations and for not agreeing to card check neutrality. This removes the harshest antiunion firm from the city negotiations, while also threatening the Hyatt with targeted job actions.

In 2000, UNITE-HERE initiated a strategy which attempts to use the leverage they still enjoy in union enclaves such as New York to reorganize the rest of the country's hotel industries, particularly in the large urban areas. Slowly, contract lengths in different cities have been tailored so that agreements end the same year, and by 2006 the union had lined up seven North American cities in which hotel contracts were to expire or had already expired. These include jurisdictions of strong union power such as New York, San Francisco, Toronto and Honolulu, as well as areas where the union is weak, such as Los Angeles, Chicago and Boston. In San Francisco, Los Angeles and Toronto workers have been kept without a contract (in the case of San Francisco for almost two years) in order for negotiations to continue into 2006. This strategy is aimed at overcoming the ability of national firms to break local strikes by continuing operations across the country, ensuring income flows, as was the case with the 2003-4 California grocery strike. Sympathy strikes in one city to support negotiations in another are illegal as per the terms of Taft-Hartley, and the New York hotel unions are not inclined, in any event, to stay out longer or work without a contract in support of a local in Los Angeles. The International hopes, however, that if contracts are synchronized across these different cities it is more likely that job actions could be widened to cover a larger proportion of the corporation's markets, and more likely that they would involve urban markets where the union is strongly placed. It is this kind of thinking that could take an anomaly like New York and make it work for the rest of the country's labour movement.

\section{Conclusion}

Understood as a political project to turn back the gains that the organized working class was able to make within postwar capitalism, neoliberalism has everywhere undermined the power of organized labour and narrowed the space for public policies which do not accord with, much less contradict, the requirements for the accumulation of capital. Just as the compromises of the postwar era and the institutions in which they crystallized varied across space, so too does the neoliberal reworking of these compromises vary. New York is not less or more neoliberal, but does represent a different outcome. This paper has shown how, due to a complex of political economic factors leading up to the transition to neoliberalism, the city's labour movement has managed to retain the institutional sources of its power even if politically it is a shadow of its former self. The relevance of this finding is not limited to an understanding of how variations in neoliberalism occur but, further, how projects of political resistance may spring from these differences. As what might still be called a 
'union town', New York City should therefore figure more prominently in the thinking that must be done on the 'revitalization' of the American labour movement.

The strategies pursued by the hotel workers and food retail workers discussed above exemplify this dynamic. Even if UNITE-HERE is attempting to leverage the power it retains in New York to raise wages and labour standards in other major urban centers, while the more defensive UFCW is unwilling to attempt the same with respect to the food retail sector, neither strategy amounts to a contestation of the ways in which capital has reshaped the political economy of the city's urban development. Indeed, the hotel workers' strategy is all but explicitly premised on global city formation. The unions which have contested the transformation of New York City from the workshop of the nation to global center of financial capital have nearly entirely disappeared from the landscape. Many of those which remain represent workers in the industries necessary, or ancillary, to global city formation. The ambiguity that this entails - between defending the economic interests of their members while lending political support to an urban development strategy with regressive social implications - may be indicative of trade union power more generally under neoliberalism. 
Figure 1: Union density in the New York Metropolitan Region, New York State, and the United States (1974-2008)

Union Density in the New York Metropolitan Region, New York State, and the United States (1974-2008)

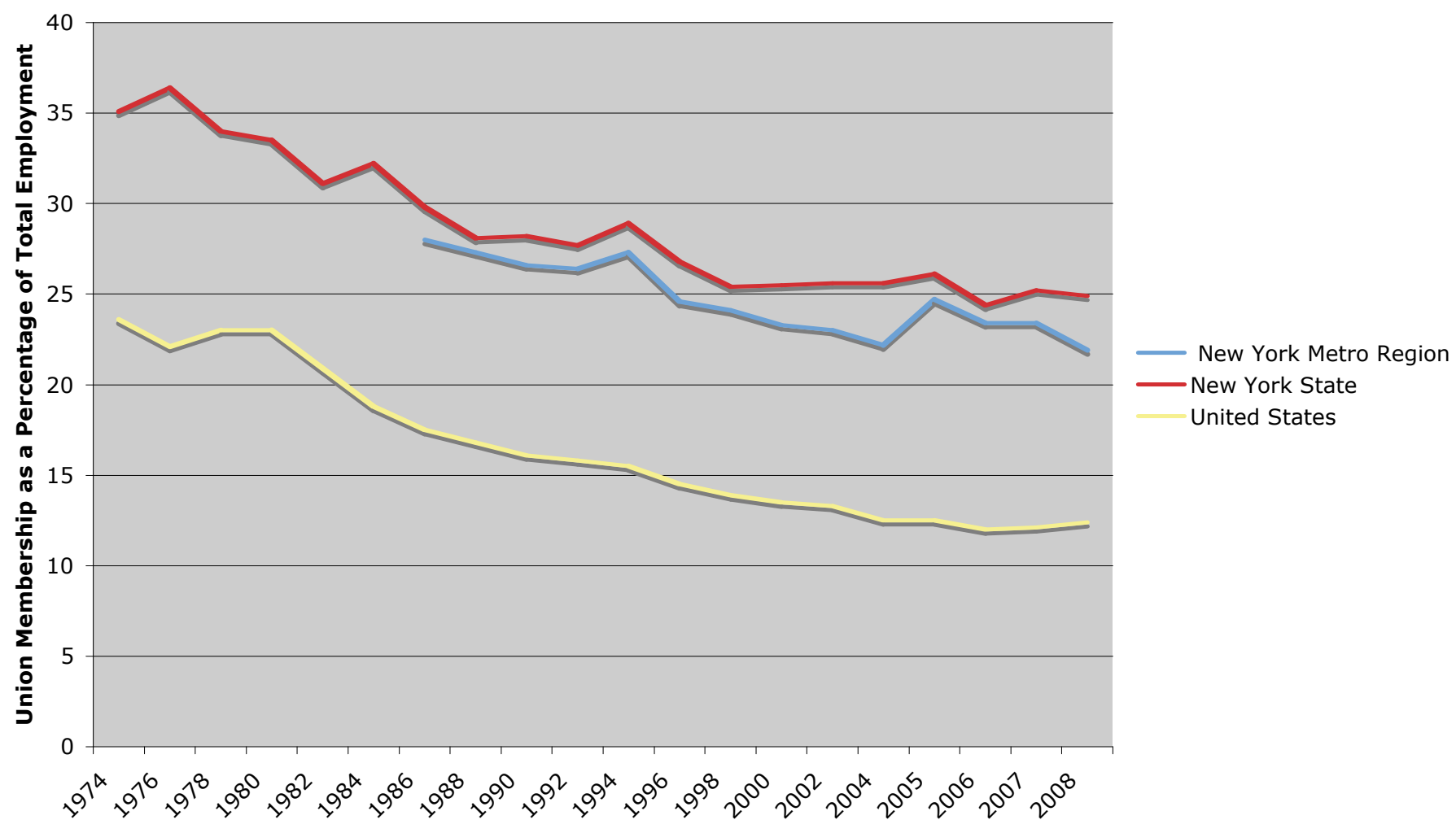

Source: Bureau of Labor Statistics figures

\section{ACKNOWLEDGEMENTS}

I would like to acknowledge the financial support of the Social Sciences and Humanities Research Council of Canada, and the institutional support of the CUNY Graduate Center in New York. I am also indebted to the anonymous reviewers of this Journal for their helpful comments. 


\section{NOTES}

${ }^{1}$ Figures compiled by Barry Hirsch and David MacPherson from the Current Population Survey, available at www.unionstats.com. Union density in the US increased marginally in 2007 and 2008, to 12.4 percent of the total workforce and 7.6 percent of the private sector. (Accessed 7 April 2009)

${ }^{2}$ Figures from the Bureau of Labor Statistics, [www.bls.gov] (Accessed 28 October 2008)

${ }^{3}$ Figures from www.unionstats.com (Accessed on 4 April 2009)

${ }^{4}$ Some work in US labour studies has developed Herbert Gutman's insights into the relationship between community and working class formation, most notably Gordon, D. (1978) 'Capitalist Development and the History of American Cities', in Tabb, W.K. and Sawers, L. (eds) Marxism and the Metropolis: New Perspectives in Urban Political Economy. New York: Oxford University Press; and Earles, C. (1992) Geographical Inquiry and American Historical Problems. Stanford: Stanford University Press. The literature on trade union decline in Britain has been far more attuned to geography, reflecting perhaps the stronger tradition of geographical thinking in that country. See, for example, Massey, D. (1984) Social Divisions of Labour. London: Routledge; Griffiths, M.J. and Johnston, R.J. (1991) 'What's in a Place? An Approach to the Concept of Place, as Illustrated by the British National Union of Mineworkers Strike, 1984-5', Antipode 23(2): 185-213; Wills, J. (1996) 'Geographies of Trade Unionism: Translating Traditions Across Space and Time', Antipode 28(4): 352-378.

${ }^{5}$ The following are representative: Turner, L. and Cornfield, D.B. (2007) Labor in the New Urban Battlegrounds. Ithaca: Cornell University Press; and Moody, K. (2007) From Welfare State to Real Estate: Regime Change in New York City, 1974 to the Present. New York: The New Press.

${ }^{6}$ A recent ranking by Foreign Policy scored New York first in its Global City Index due to the depth of its financial markets, the connectivity of its home-based multinationals, and 'the strength of its diverse creative class'. Foreign Policy (2008) 'Global City Index', Foreign Policy, NovemberDecember. While it is too early to evaluate the implications of the credit crisis for New York as a global city, the US government bailout of its banking sector underlines the importance of the city's financial markets and institutions to the functioning of the American economy, while the importance given to the bailout by world markets speaks to the continued centrality of New York in the global city network.

${ }^{7}$ This was not true of the city's professional services, finance and insurance, wholesale retailing and garment industries, which dominated their respective national markets. Nevertheless, Martin Segal's study for the RPA estimated that 59 percent of the New York Metropolitan region's labour force in the late 1940s and early 1950s was engaged in supplying goods and services to local industries and consumers. 
${ }^{8}$ The tendency in public sector labour relations to widen the scope of bargaining to include service levels and the work process also raised the possibility of dynamic labour-community-recipient coalitions. The Social Service Employees Union, for example, built an effective alliance with the civil and welfare rights movements by incorporating its demands in its negotiation with the city, thus broadening the basis of its support in a difficult strike that stopped welfare checks from being delivered.

${ }^{9}$ Spending rose five-fold between 1960 to 1975 (Abu-Lughod 1999: 312).

${ }^{10}$ This disproportion is lessened when county and state workers are added to the Chicago figures (Fuchs 1992: 112, 124). New York City performs functions which in Chicago would be performed by other jurisdictions.

${ }^{11}$ This brief account of the fiscal crisis relies on Tabb, W. (1982) The Long Default: New York City and the Urban Fiscal Crisis. New York: Monthly Review Press.

${ }^{12}$ See, for example, the neoliberal view in Gujarati, D. (1978) Pensions and New York City's Fiscal Crisis. Washington: American Enterprise Institute.

${ }^{13}$ Michael Spear's dissertation admirably details the political transformation of the city's municipal unions in this period.

${ }^{14}$ This section is informed by discussions with Ed Ott, former Education Director and current President of the New York City Central Labour Council, March 2006; Kim Moody, labour journalist and professor of labour studies, Queen's College, CUNY, January 2006; and Joshua Freeman, Professor of History, CUNY Graduate Center, March 2006.

${ }^{15}$ In interview with Ed Ott, op cit. Ed Ott was made executive director of the labor council after his predecessor, Brian McLaughlin, was indicted by the FBI on 44 counts of fraud.

${ }^{16}$ In interview with Herman Benson, founder, Association for Union Democracy, February 2006.

${ }^{17}$ On corruption in the New York City construction trades see the Final Report of the New York State Organized Crime Task Force (1990) Corruption and Racketeering in the New York City Construction Industry. New York: New York University Press.

${ }^{18}$ Figures from the Bureau of Labour Statistics, www.bls.gov.us (Accessed 11 May 2006)

${ }^{19}$ This discussion of UFCW strategy is based on an interview with UFCW local 1500 organizing director Pat Purcell, April 2006. 
20 'Show me a hotel that doesn't contribute to its employees' health care costs, and I'll show you a hotel we could organize in fifteen minutes' sums up the perspective of the hotel unions on city-wide health care initiatives. In interview with John Turchiano, New York Hotel-Motel Trades Alliance, April 2005.

${ }^{21}$ In interview with Ann Thomas, media relations, Health Committee, New York City Council, April 2006; and Lauren Barker, Jobs with Justice, April 2005.

${ }^{22}$ In interview with Pat Purcell.

${ }^{23}$ According to the Hotel Association of New York, telephone interview.

${ }^{24}$ In interview with John Turchiano, Hotel-Motel Trades Council of New York, April 2005.

${ }^{25}$ This discussion of the New York Hotel-Motel Council strategy in 2006 is informed by a conversation with NYHMC representative John Turchiano.

\section{REFERENCES}

Abu-Lughod, J.L. (1999) New York, Chicago, Los Angeles: America's Global Cities. Minneapolis: University of Minnesota Press.

Aronowitz, S. (1991) False Promises: The Shaping of American Working Class Consciousness. Durham: Duke University Press.

Bailey, R.W. (1984) The Crisis Regime: the MAC, the EFCB and the Political Impact of the New York City Financial Crisis. Albany: SUNY Press.

Beckert, S. (2001) The Monied Metropolis. Cambridge: Cambridge University Press.

Beveridge, A. (2003) 'The Affluent of New York', The Gotham Gazette, June. http:/www.gothamgazette.com/article/demographics/20030611/5/421 (Accessed 22 April 2009).

Brenner, N. and Theodore, N. (2002) 'Cities and the Geographies of 'Actually Existing Neoliberalism', in N. Brenner and N. Theodore (eds) Spaces of Neoliberalism (pp. 2-32). New York: Basic Books.

Castree, N., Coe, N., Ward, K. and Samers, M. (2004) Spaces of Work: Global Capitalism and Geographies of Labour. London: Sage Publications. 
Cowie, C.R. (1999) Capital Moves: RCA's Seventy-year Quest for Cheap Labor. Ithaca: Cornell University Press.

Davis, M. (1986) Prisoners of the American Dream: Politics and Economy in the History of the American Working Class. London: Verso.

Drennan, M.P. (1991) 'The Decline and Rise of the New York Economy', in J.H. Mollenkopf and M. Castells (eds) Dual City: Restructuring New York (pp. 25-42). New York: Russell Sage Foundation.

Dubofsky, M. (1968) When Workers Organize: New York City in the Progressive Era. Amherst: University of Massachusetts Press.

Edwards, R., Goronna, P., and Todling, F. (eds.) (1986) Unions in Crisis and Beyond: Perspectives From Six Countries. Dover, MA: Auburn House Publishing.

Fantasia, R. and Voss, K. (2004) Hard Work: Remaking the American Labor Movement. Berkeley: University of California Press.

Fiscal Policy Institute. (2005) Taking Away the Ladder of Opportunity: Hotel Conversions and the Threat Posed to New York City's Tourism Jobs and Economic Diversity. http://www.fiscalpolicy.org/research_labormarketanalysis.html. (Accessed 22 April 2009)

Fitch, R. (1993) The Assassination of New York. New York: Verso.

Foreign Policy. (2008) 'Global City Index’, Foreign Policy, November-December.

Freeman, J. (2001) Working Class New York: Life and Labor Since World War II. New York: The New Press.

Fuchs, E. F. (1992) Mayors and Money: Fiscal Policy in New York and Chicago. Chicago: University of Chicago Press.

Gabriel, F. (1997) 'Sheraton Exhibits Yen for Business; Reduces Scarce Convention Space to Pursue Corporate Travelers', Crain's New York Business, 24 March 1997.

Griffin, J.I. (1955) Industrial Location. New York: City College Press.

Griffith, B.S. (1988) The Crisis of American Labour: Operation Dixie and the Defeat of the CIO. Philadelphia: Temple University Press. 
Griffiths, M.J. and Johnston, R.J. (1991) 'What's in a Place? An Approach to the Concept of Place, as Illustrated by the British National Union of Mineworkers Strike, 1984-5', Antipode 23(2): 185213.

Gujarati, D. (1978) Pensions and New York City's Fiscal Crisis. Washington: American Enterprise Institute.

Haig, R.M. (1974 [1929]) Regional Survey of New York: Major Economic Factors in Metropolitan Growth and Arrangement, vol. 1. New York: Regional Plan of New York and Environs.

Harvey, D. (1978) 'From Managerialism to Entrepreneurialism: The Transformation in Urban Governance in Late Capitalism', Geographsker Annaler 71(B): 3-17.

Harvey, D. (2005) A Brief History of Neoliberalism. Oxford: Oxford University Press.

Herod, A. (1994) 'On Workers' Theoretical (In)visibility in the Writing of Critical Urban Geography: A Comradely Critique', Urban Geography 15(7): 681-693.

Herod, A. (1997) 'From a Geography of Labor to a Labor Geography: Labor's Spatial fix and the Geography of Capitalism', Antipode 29(1): 1-31.

Herod, A. (2001) Labor Geographies. New York: Guildford Press.

Hoover, E. and Vernon, R. (1959) Anatomy of a Metropolis. Cambridge, MA: Harvard University Press.

Horton, R.D. (1973) Municipal Labour Relations in New York City: Lessons of the Lindsay-Wagner Years. New York: Praeger.

Jackson, K. (1984) 'The Capital of Capitalism: The New York Metropolitan Region, 1890-1940', in A. Sutcliffe (ed) Metropolis: 1890-1940. Chicago: University of Chicago Press.

Josephson, M. (1956) Union House, Union Bar. New York: Random House.

Kahler, M. (1993) 'New York City and the International System: International Strategy and Urban Fortunes', in M. Shefter (ed) Capital of the American Century: The National and International Influence of New York City (pp. 27-48). New York: Russell Sage Foundation.

Kriesky, J. (2001) 'Structural Change in the AFL-CIO: A Regional Study of Union Cities' Impact', in L. Turner, C. Katz, and R.W. Hurd (eds) Rekindling the Movement: Labor's Quest for Relevance in the Twenty-first Century (pp. 129-154). Ithaca: Cornell University Press. 
Lefebvre, H. (1974) The Production of Space. New York: Basic Books.

Lewin, D. and McCormick, M. (1981) 'Coalition Bargaining in Municipal Government: The New York City Experience', Industrial and Labour Relations Review 34(2): 175-190.

Lipset, S.M. (1995) 'Trade Union Exceptionalism: the United States and Canada', ANNALS, AAPSS 538(1): 115-130.

Lipset, S.M. and Meltz, N.M. (2004) The Paradox of American Unionism: Why Americans Like Unions More Than Canadians Do But Join Much Less. Ithaca: Cornell University Press.

Lipsitz, G. (1994) Rainbow at Midnight: Labour and Culture in the 1940s. Urbana: University of Illinois Press.

Mantsios, G. (ed.) (1998) A New Labor Movement for the New Century. New York: Monthly Review.

Milkman, R. and Voss, K. (2004) Rebuilding Labor: Organizing and Organizers in the New Union Movement. Ithaca: Cornell University Press.

Moody, K. (1988) An Injury to All: The Decline of American Unionism. New York: Verso.

Moody, K. (2007) From Welfare State to Real Estate: Regime Change in New York City, 1974 to the Present. New York: The New Press.

Ness, I. and Eimer, S. (eds.) (2001) Central Labor Councils and the Revival of American Unionism. New York: M.E. Sharpe.

New York City. (1991) Citywide Industry Study: Labour Force Technical Report. New York: Department of City Planning.

New York State Organized Crime Task Force, (1990) Corruption and Racketeering in the New York City Construction Industry. New York: New York University Press.

Panitch, L. and Gindin, S. (2004) 'Finance and American Empire', in L. Panitch and C. Leys (eds) Socialist Register 2005: The Empire Reloaded (pp. 46-81). New York: Monthly Review Press

Parrott, J.A. (2001) 'Bolstering and Diversifying New York City's Economy', in J. Mollenkopf and K. Emmerson (eds) Rethinking the Urban Agenda (pp. 41-62). New York: The Century Foundation.

Pratt Center for Community Development (2001) Making it in New York: Manufacturing Land Use and Zoning Initiative. New York: Pratt Center for Community Development. 
Pratt, E.E. (1968 [1911]) Congestion of Population in New York City. New York: Columbia University Press.

Rathke, W. and Rogers, J. (2001) “Everything that Moves”: Union Leverage and the Critical Mass in Metropolitan Space', in I. Ness and S. Eimer (eds) Central Labor Councils and the Revival of American Unionism (pp. 35-53). New York: M.E. Sharpe.

REAP (2006) A Review of the US Grocery Store Industry. http://www.reapinc.org/Profile\%20Grocery.htm (Accessed 24 March 2006)

Renwick, T. (2006) Pulling Apart in New York: An Analysis of Income Trends in New York State. New York: Fiscal Policy Institute.

Saskia, S. (1991) 'The Informal Economy', in J.H. Mollenkopf and M. Castells (eds) Dual City: Restructuring New York. New York: Russell Sage Foundation.

Segal, M. (1960) Wages in the Metropolis: Their Influence on the Location of Industries in the New York Region. Cambridge, MA: Harvard University Press.

Shefter, M. (1985) Political Crisis/Fiscal Crisis: The Collapse and Revival of New York City. New York: Basic Books.

Shefter, M. (1993) 'New York City and American National Politics', in M. Shefter (ed) Capital of the American Century: The National and International Influence of New York City (pp. 95-116) New York: Russell Sage Foundation.

Spear, M. (2005) A Crisis in Urban Liberalism: The New York City Municipal Unions and the 1970s Fiscal Crisis. PhD Dissertation, City University of New York.

Tabb, W. (1982) The Long Default: New York City and the Urban Fiscal Crisis. New York: Monthly Review Press.

Tufts, S. (1998) 'Community Unionism in Canada and Labor's (Re)organization of Space', Antipode 30(3): 227-250.

Tufts, S. (2006) “We Make It Work”: The Cultural Transformation of Hotel Workers in the City', Antipode 38(2): 350-73.

Turner, L. (1999) Democracy at Work: Changing World Markets and the Future of Labor Unions. Ithaca: Cornell University Press. 
Turner, L. and Cornfield, D.B. (2007) Labor in the New Urban Battlegrounds. Ithaca: Cornell University Press.

UNITE-HERE. (2006) 'Corporate Consolidation in the Hotel Industry', http://www.unitehere2.org/issues.html (Accessed 12 May 2006)

Vernon, R. (1960) Metropolis 1985: An Interpretation of the Findings of the New York Metropolitan Region Study. New York: Sage Publications.

Wills, J. (1996) 'Geographies of Trade Unionism: Translating Traditions Across Space and Time', Antipode 28(4): 352-378.

Zevin, R. (1977) 'New York City Crisis: First Act in a New Age of Reaction', in R.E. Alcaly and D. Mermelstein (eds) (1977) The Fiscal Crisis of American Cities (pp. 11-29). New York: Random House.

\section{BIOGRAPHICAL NOTE}

IAN THOMAS MACDONALD is currently completing a $\mathrm{PhD}$ in Political Science at York University in Toronto, Canada. His research interests include continental economic integration, labour law reform, the North American labour movement, and urban political economy. His dissertation, Labour and the City: Spatial Foundations of Trade Union Power in Toronto and New York' concerns the implications for production relations and collective bargaining of global city formation. 